Review

\title{
Solid-Liquid Phase $C$-Alkylation of Active Methylene Containing Compounds under Microwave Conditions
}

\author{
Alajos Grün ${ }^{1, *}$, Erika Bálint ${ }^{2}$ and György Keglevich ${ }^{1, *}$ \\ 1 Department of Organic Chemistry and Technology, Budapest University of Technology and \\ Economics, 1521 Budapest, Hungary \\ 2 MTA-BME Research Group for Organic Chemical Technology, 1521 Budapest, Hungary; \\ E-Mail: ebalint@mail.bme.hu \\ * Authors to whom correspondence should be addressed; E-Mails: agrun@mail.bme.hu (A.G.); \\ gkeglevich@mail.bme.hu (G.K.); Tel.: +36-1-463-1111 (ext. 5897) (A.G.); (ext. 5883) (G.K.); \\ Fax: +36-1-463-3648 (A.G. \& G.K.).
}

Academic Editor: Domenico Albanese

Received: 4 February 2015 / Accepted: 7 April 2015 / Published: 21 April 2015

\begin{abstract}
The solid-liquid phase $C$-alkylation of active methylene containing compounds with $\mathrm{C}=\mathrm{O}$ or $\mathrm{P}=\mathrm{O}$ functions under phase transfer catalysis or microwave conditions has been summarized in this minireview. The mono- and dialkylation of the methylene containing derivatives was investigated under microwave (MW) conditions. It was found that in many cases, there was no need to use phase transfer catalyst under MW conditions. Moreover, most of the reactions were carried out without any solvent. These results mean a serious green chemical advantage.
\end{abstract}

Keywords: compounds with active methylene group; $C$-alkylation; microwave irradiation; phase transfer catalysis; solvent-free reaction; green synthesis

\section{Introduction}

Today, the use of the microwave (MW) technique is becoming more widespread in the implementation of the various reactions [1-3]. The MW irradiation is considered a kind of molecular heater, where the MWs are taken up directly by the reagents, and the beneficial effect is that reluctant reactions may take place faster. The MW irradiation causes statistically occurring local overheating in 
the mixture, and as a consequence of this, the activation barrier may be overcome easier, and the reaction rate increases, and the efficiency is improved [4,5]. There are already $\mathrm{MW}$-assisted processes in the $\mathrm{R}+\mathrm{D}$ segment of the pharmaceutical industry, but the real challenge is the scale-up [6,7].

Phase transfer catalysis (PTC) is also an environmentally friendly tool. The typical phase transfer catalysts are quaternary ammonium or phosphonium salts, as well as crown ethers, which are used in heterogeneous reaction mixtures to facilitate the transfer of a reactant from one phase to another. There are liquid-liquid (L-L) and solid-liquid (S-L) two-phase systems. As typical cases, substitutions, alkylations, acylations, additions, eliminations, oxidations and reductions may be implemented under PTC conditions. The reactions take place usually under mild conditions, and involve easy work-up procedures. A number of phase transfer catalytic processes have spread in the industry, especially in the pharmaceutical and plastics industries [8-11]. In these cases, the catalysts are usually bound to solid supports.

The combination of PTC and MW techniques offers further advantages, such as additional increase in the reaction rate and selectivity [2].

\section{Alkylation of Active Methylene Containing Substrates under MW Conditions}

Alkylation of the title compounds is a well-known and well-studied reaction. However, the use of the MW technique is relatively new in this area. Only a few publications deal with the alkylation of active methylene containing substrates, such as diethyl malonate, ethyl acetoacetate, ethyl phenylsulfonylacetate, and ethyl phenylmercaptoacetate under MW conditions [12-15].

The solvent-free solid-liquid phase alkylation of diethyl malonate (1) was carried out in a domestic MW oven by Wang et al. (Scheme 1) [10]. The alkylating agents were different alkyl halides, such as normal and substituted benzyl chloride, allyl bromide and butyl bromide. $\mathrm{K}_{2} \mathrm{CO}_{3}$ (4 equiv.) was applied as the base, and $10 \%$ of tetrabutylammonium bromide (TBAB) was used as the phase transfer catalyst. Mono- and dialkylated malonic esters ( 2 and $\mathbf{3}$ ) were formed in the reaction.

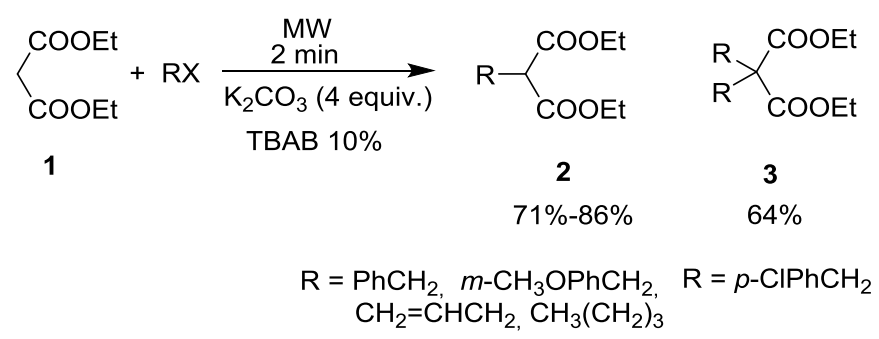

Scheme 1. Alkylation of diethyl malonate (1) under microwave (MW) conditions.

Deng and his research group have studied the solid-liquid phase alkylation of ethyl acetoacetate (4) under MW conditions using a catalyst (Scheme 2) [13]. Their experiments were carried out in a domestic MW oven. The 1:4 mixture of $\mathrm{KOH}$ and $\mathrm{K}_{2} \mathrm{CO}_{3}$ was used as in an excess, and the catalyst was triethylbenzylammonium chloride (TEBAC) in a quantity of $10 \%$. The alkylations were performed with benzyl- and $p$-chlorobenzyl bromide, $m$-methoxybenzyl chloride, allyl bromide and butyl bromide at 60-80 ${ }^{\circ} \mathrm{C}$ for $3-4.5 \mathrm{~min}$. The $C$-alkylated derivatives of acetoacetic ester (5) were obtained in a $59 \%-82 \%$ yield. 


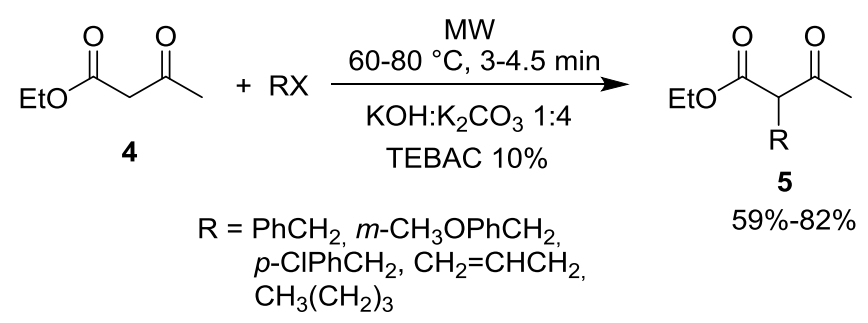

Scheme 2. Alkylation of ethyl acetoacetate (4) under MW conditions.

The alkylation of ethyl phenylsulfonylacetate (6) was investigated by Wang et al. with a series of alkyl halides in a domestic MW oven, and the mono-alkylated products (7) were isolated in yields of $76 \%-86 \%$ (Scheme 3) [14].

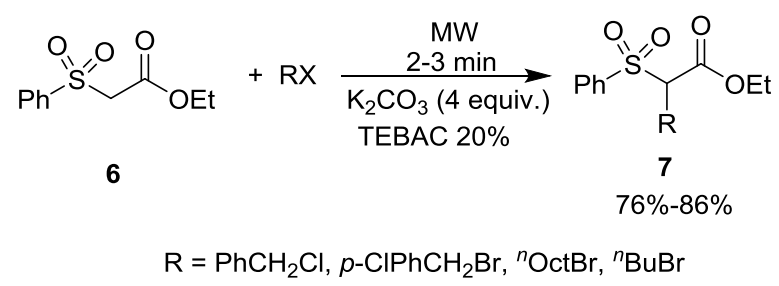

Scheme 3. Alkylation of ethyl phenylsulfonylacetate (6) under MW conditions.

Chinese researchers carried out the reaction of ethyl phenylmercaptoacetate $(\mathbf{8})$ with different alkyl halides, such as benzyl- and $m$-methoxybenzyl chloride, as well as allyl-, butyl- and $p$-chlorobenzyl bromide in a domestic MW oven in the presence of 2.6 equivalents of $\mathrm{KOH}-\mathrm{K}_{2} \mathrm{CO}_{3}$ and $10 \%$ of tetrabutylammonium chloride (TBAC). The yields of the alkylated products fell in the range of $58 \%-83 \%$ (Scheme 4) [15].

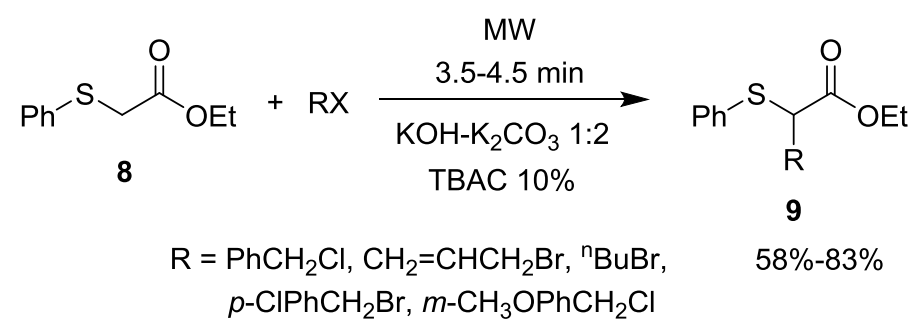

Scheme 4. Alkylation ethyl phenylmercaptoacetate (8) under MW conditions.

Indian scientists synthesized disubstituted cyclopropane derivatives (10) from active methylene containing compounds and 1,2-dibromoethane by a MW-assisted and phase transfer catalyzed solvent-free approach (Scheme 5) [16].

$$
\begin{aligned}
\mathrm{R}^{1} & \mathrm{R}^{2}+\mathrm{BrCH}_{2} \mathrm{CH}_{2} \mathrm{Br} \underset{ }{\stackrel{\mathrm{MW}}{10 \mathrm{~min}} \underset{\mathrm{K}_{2} \mathrm{CO}_{3}}{\longrightarrow}} \mathrm{R}^{1} \mathrm{C}^{2} \\
\mathrm{R}^{1}= & \mathrm{CO}_{2} \mathrm{Et}, \mathrm{C}(\mathrm{O}) \mathrm{CH}_{3}, \\
& \mathrm{CN}, 4-\mathrm{MePhSO}_{2} \\
\mathrm{R}^{2}= & \mathrm{CO}_{2} \mathrm{Et}, \mathrm{C}(\mathrm{O}) \mathrm{CH}_{3}
\end{aligned}
$$

Scheme 5. MW-assisted solvent-free synthesis of cyclopropane derivatives (10). 
The alkylation of simple compounds with active methylene group was also studied by Keglevich et al. under MW heating [17-19]. A MW-promoted, solvent-free method was developed for the solid-liquid phase alkylation of diethyl malonate (1), ethyl acetoacetate (4) and ethyl cyanoacetate (14) using different alkyl halides in the presence of $\mathrm{K}_{2} \mathrm{CO}_{3}$ or $\mathrm{Cs}_{2} \mathrm{CO}_{3}$. There was no need to apply a phase transfer catalyst (Scheme 6, Table 1).

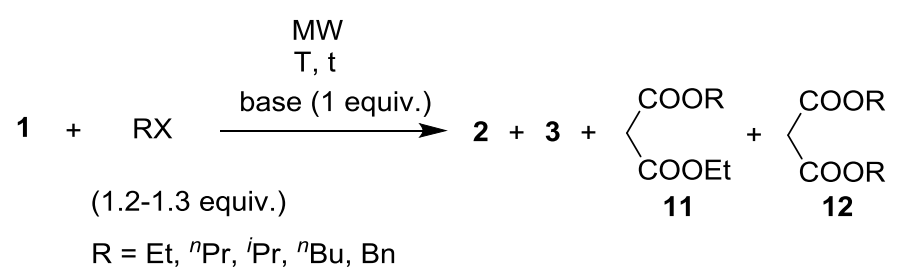

Scheme 6. Alkylation of diethyl malonate (1) with MW promoted methods.

Table 1. Alkylation of diethyl malonate (1) under microwave (MW) and solvent-free conditions.

\begin{tabular}{cccccccc}
\hline Entry & $\boldsymbol{R X}$ & Base & $\boldsymbol{T}\left({ }^{\circ} \mathbf{C}\right)$ & $\boldsymbol{t}(\mathbf{m i n})$ & Yield of 2 (\%) & By-products & Ref. \\
\hline 1 & $\mathrm{EtI}$ & $\mathrm{K}_{2} \mathrm{CO}_{3}$ & 160 & 45 & 93 & $3 \% 3(R=\mathrm{Et})$ & 18 \\
2 & $\mathrm{EtI}$ & $\mathrm{Cs}_{2} \mathrm{CO}_{3}$ & 140 & 90 & 97 & $3 \% 3(R=\mathrm{Et})$ & 19 \\
3 & ${ }^{n} \mathrm{PrBr}$ & $\mathrm{K}_{2} \mathrm{CO}_{3}$ & 185 & 45 & 97 & $2 \% 3\left(R={ }^{n} \mathrm{Pr}\right)$ & 18 \\
& & & & & & $33 \% 11\left(R={ }^{n} \mathrm{Pr}\right)$ & 19 \\
4 & ${ }^{n} \mathrm{PrBr}$ & $\mathrm{Cs}_{2} \mathrm{CO}_{3}$ & 120 & 240 & 57 & $10 \% 12\left(R={ }^{n} \mathrm{Pr}\right)$ & \\
5 & ${ }^{i} \mathrm{PrBr}$ & $\mathrm{K}_{2} \mathrm{CO}_{3}$ & 185 & 60 & 92 & - & 18 \\
6 & ${ }^{n} \mathrm{BuBr}$ & $\mathrm{K}_{2} \mathrm{CO}_{3}$ & 185 & 45 & 88 & $5 \% 3\left(R={ }^{n} \mathrm{Bu}\right)$ & 18 \\
7 & $\mathrm{BnBr}$ & $\mathrm{K}_{2} \mathrm{CO}_{3}$ & 180 & 45 & 68 & $1 \% 3(R=\mathrm{Bn})$ & 18 \\
\hline
\end{tabular}

The alkylation of diethyl malonate (1) was examined in detail. The reaction with ethyl iodide at $160{ }^{\circ} \mathrm{C}$ for $45 \mathrm{~min}$ in the presence of $\mathrm{K}_{2} \mathrm{CO}_{3}$ led to $93 \%$ yield of the monoalkylated product $(2, R=\mathrm{Et}$ ) (Table 1 , entry 1). When $\mathrm{Cs}_{2} \mathrm{CO}_{3}$ was used at a lower temperature and for a longer reaction time, the result was similar (Table 1, entry 2). In both cases, a few percent of the diethylated derivative $(\mathbf{3}, R=\mathrm{Et})$ was also detected.

Using propyl bromide or butyl bromide in the presence of $\mathrm{K}_{2} \mathrm{CO}_{3}$ without phase transfer catalyst, a higher temperature $\left(185^{\circ} \mathrm{C}\right)$ was necessary to obtain higher conversions (Table 1, entries 3 and 6$)$. When $\mathrm{Cs}_{2} \mathrm{CO}_{3}$ was applied as the base at $120{ }^{\circ} \mathrm{C}$ for $4 \mathrm{~h}$, beside the propylated product $\left(2, R={ }^{n} \operatorname{Pr}\right)$ other transesterified derivatives were also formed (33\% of 11, $R={ }^{n} \operatorname{Pr}$ and $10 \%$ of $12, R={ }^{n} \operatorname{Pr}$ ) (Table 1, entry 4). For the alkylation with isopropyl bromide, a longer reaction time was required due to the steric hindrance (Table 1, entry 5).

The benzylation of diethyl malonate (1) with the more reactive benzyl bromide resulted in a yield of $68 \%$ after a $45 \mathrm{~min}$ irradiation at $180{ }^{\circ} \mathrm{C}$ (Table 1 , entry 6). The use of a phase transfer catalyst led to the formation of by-products. The two by-products, $\mathrm{BnCH}_{2} \mathrm{CO}_{2} \mathrm{Et}$ and $(\mathrm{Bn})_{2} \mathrm{CHCO}_{2} \mathrm{Et}$ may have been formed by the de-ethoxycarbonylation of diethyl benzylmalonate and diethyl dibenzylmalonate, respectively.

Ethyl acetoacetate (4) was more reactive in the alkylations (Scheme 7, Table 2) [18]. 


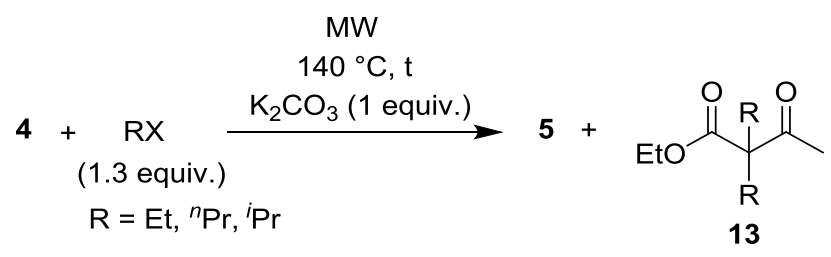

Scheme 7. Alkylation of ethyl acetoacetate (4) under MW conditions.

Table 2. Alkylation of ethyl acetoacetate (4) under MW and solvent-free conditions

\begin{tabular}{ccccc}
\hline Entry & $\boldsymbol{R X}$ & $\boldsymbol{t}(\mathbf{m i n})$ & Yield of 5 (\%) & By-products \\
\hline 1 & $\mathrm{EtI}$ & 30 & 85 & $5 \% 13(R=\mathrm{Et})$ \\
2 & ${ }^{n} \mathrm{PrBr}$ & 30 & 87 & $2 \% 13\left(R={ }^{n} \mathrm{Pr}\right)$ \\
3 & ${ }^{i} \mathrm{PrBr}$ & 45 & 83 & - \\
\hline
\end{tabular}

In the alkylation with ethyl iodide and propyl bromide at $140{ }^{\circ} \mathrm{C}$ for $30 \mathrm{~min}$, the mono-alkylated products $\left(5, R=\mathrm{Et},{ }^{n} \mathrm{Pr}\right)$ were obtained in good yields, and only a few percent of the dialkylated by-products (13, $R=\mathrm{Et},{ }^{n} \mathrm{Pr}$ ) was formed (Table 2, entries 1 and 2). In the case of isopropyl bromide, a longer reaction time was required to achieve an acceptable yield (Table 2, entry 3 ).

In the series of model compounds studied by a part of the authors of this article, ethyl cyanoacetate (14) was the most reactive methylene containing substrate (Scheme 8, Table 3) [18].

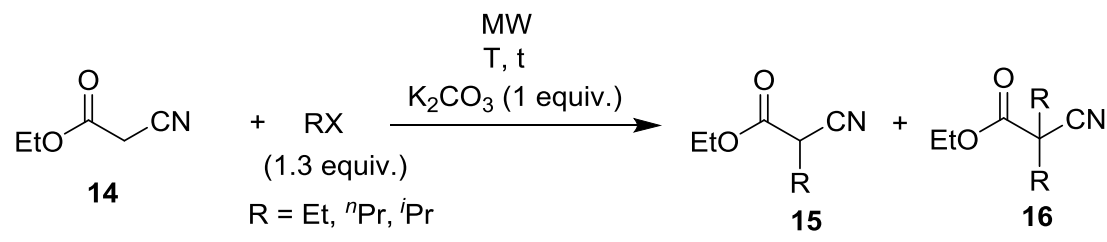

Scheme 8. Alkylation of ethyl cyanoacetate (14) under MW conditions.

Table 3. Alkylation of ethyl cyanoacetate (14) under MW and solvent-free conditions.

\begin{tabular}{cccccc}
\hline Entry & $\boldsymbol{R X}$ & $\boldsymbol{T}\left({ }^{\circ} \mathbf{C}\right)$ & $\boldsymbol{t}(\mathbf{m i n})$ & Yield of 15(\%) & By-products \\
\hline 1 & EtI & 100 & 60 & 78 & $12 \% 16(R=\mathrm{Et})$ \\
2 & $\mathrm{EtI}$ & 120 & 45 & 76 & $23 \% 16(R=\mathrm{Et})$ \\
& & & & & $10 \% 16\left(R={ }^{n} \mathrm{Pr}\right)$ \\
3 & ${ }^{n} \mathrm{PrBr}$ & 120 & 45 & 82 & $5 \% \mathrm{NCCH}^{n} \mathrm{PrCO}{ }^{n} \mathrm{Pr}$ \\
& & & & & $<1 \% 16\left(R={ }^{n} \operatorname{Pr}\right)$ \\
4 & ${ }^{i} \mathrm{PrBr}$ & 140 & 45 & 86 & $13 \% \mathrm{NCCH}^{i} \operatorname{PrCO}{ }_{2}^{i} \mathrm{Pr}$ \\
& & & & & $\left.1 \% \mathrm{NCC}^{i} \operatorname{Pr}\right)_{2} \mathrm{CO}_{2}{ }^{i} \mathrm{Pr}$ \\
\hline
\end{tabular}

Applying ethyl iodide as the alkylating agent, the reaction was carried out in the presence of $\mathrm{K}_{2} \mathrm{CO}_{3}$ at $100{ }^{\circ} \mathrm{C}$ for $60 \mathrm{~min}$, to afford $78 \%$ of the mono-alkylated product $(15, R=\mathrm{Et})$ and $12 \%$ of dialkylated species $(\mathbf{1 6}, R=\mathrm{Et})$. Unreacted $14(10 \%)$ was also present in the reaction mixture (Table 3, entry 1$)$. At a higher temperature $\left(120^{\circ} \mathrm{C}\right)$, the alkylation was almost complete, however, the proportion of the dialkylated by-product (16, $R=\mathrm{Et}$ ) was doubled (Table 3, entry 2). In the alkylation with $n$-propyl-bromide, $82 \%$ of the mono-alkylated product $\left(15, R={ }^{n} \operatorname{Pr}\right)$ was obtained, and a new propylester by-product appeared beside the dialkylated derivative $\left(\mathbf{1 6}, R={ }^{n} \operatorname{Pr}\right)$ (Table 3, entry 3). When 
$i$-propyl-bromide was the alkyl halide, it was necessary to apply a higher temperature $\left(140{ }^{\circ} \mathrm{C}\right)$. In this case, two derivatives formed by transesterification $\left(13 \%\right.$ of $\mathrm{NCCH}^{i} \mathrm{PrCO}_{2}{ }^{i} \mathrm{Pr}$ and $1 \%$ of $\left.\mathrm{NCC}\left({ }^{i} \mathrm{Pr}\right){ }_{2} \mathrm{CO}_{2}{ }^{i} \mathrm{Pr}\right)$ appeared beside the main product $\left(15, R={ }^{i} \mathrm{Pr}\right)$. Despite the steric hindrance, $<1 \%$ of dialkylated derivative $\left(\mathbf{1 6}, R={ }^{i} \operatorname{Pr}\right)$ was formed due to the higher temperature (Table 3, entry 4). The results showed that, in these reactions, the phase transfer catalyst can be omitted from the reaction mixture, and it is enough to use the cheaper base $\left(\mathrm{K}_{2} \mathrm{CO}_{3}\right)$.

\section{Alkylation of Active Methylene Containing Compounds with $\mathrm{P}=\mathbf{O}$ Function under MW Conditions}

The alkylation of the title compounds is much less studied according to literature data, and there are only a few references on the MW-assisted reactions.

\subsection{Alkylation of Diethyl Ethoxycarbonylmethylphosphonate under MW and Solvent-Free Conditions}

There are a few examples in the literature on the alkylation of diethyl ethoxycarbonylmethylphosphonate by conventional methods. However, the alkylation under discussion was not studied under MW conditions.

The alkylation of diethyl ethoxycarbonylmethylphosphonate (17) was described using sodium hydride in the glyme [20-24], DMF [25-27], diethyl ether [28], DMSO [29] or THF [30]. Others used potassium tert-butylate [31-35] or potassium tert-butylate/sodium iodide [36] in DMSO. The use of potassium carbonate/sodium iodide was also described [37]. Sodium in ethanol [38] or potassium in xylene [39] were also applied in a part of the alkylations (Scheme 9). Most of the papers mentioned only briefly about the alkylation as the products were only intermediates.

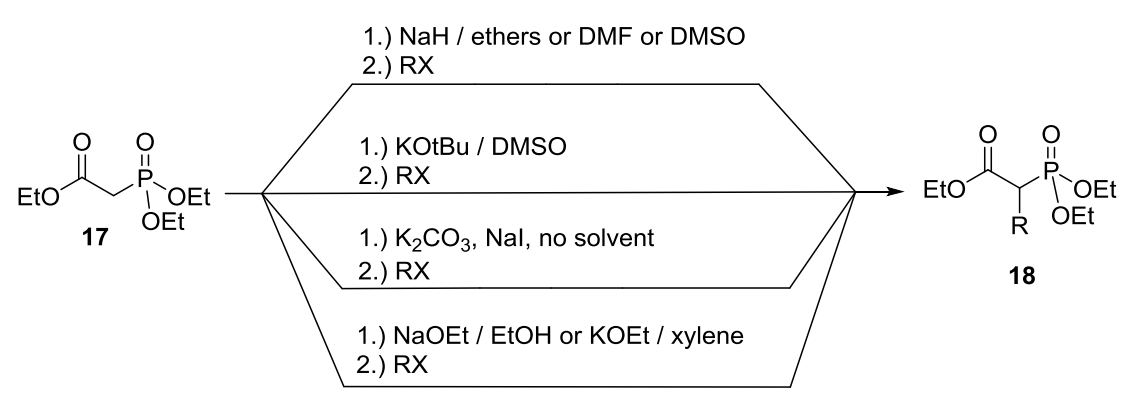

Scheme 9. The alkylation of diethyl ethoxycarbonylmethylphosphonate (17) in the literature.

The MW-assisted variation of the alkylation under discussion was studied in detail by Keglevich and Grün (Scheme 10, Table 4) [40].

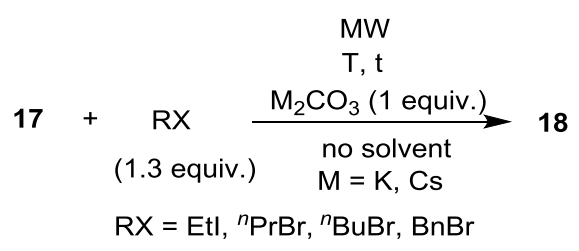

Scheme 10. Alkylation of diethyl ethoxycarbonylmethylphosphonate (17) under MW conditions. 
Table 4. Alkylation of diethyl ethoxycarbonylmethylphosphonate (17) under MW conditions.

\begin{tabular}{cccccccc}
\hline \multirow{2}{*}{ Entry } & \multirow{2}{*}{$\boldsymbol{R} \mathbf{X}$} & \multirow{2}{*}{$\boldsymbol{M}_{\mathbf{2}} \mathbf{C O}_{3}$} & \multirow{2}{*}{$\left({ }^{\circ} \mathbf{C}\right)$} & \multirow{2}{*}{$(\mathbf{h})$} & \multicolumn{3}{c}{ Composition (\%) } \\
\cline { 6 - 8 } & & & & $\mathbf{1 7}$ & $\mathbf{1 8}$ & Other \\
\hline 1 & $\mathrm{EtI}$ & $\mathrm{K}_{2} \mathrm{CO}_{3}$ & 120 & 2 & 13 & $82(R=\mathrm{Et})$ & 5 \\
2 & $\mathrm{EtI}$ & $\mathrm{Cs}_{2} \mathrm{CO}_{3}$ & 120 & 2 & 5 & $86(R=\mathrm{Et})$ & 9 \\
\hline 3 & ${ }^{n} \mathrm{PrBr}$ & $\mathrm{K}_{2} \mathrm{CO}_{3}$ & 130 & 2 & 28 & $57\left(R={ }^{n} \mathrm{Pr}\right)$ & 15 \\
4 & ${ }^{n} \mathrm{PrBr}$ & $\mathrm{Cs}_{2} \mathrm{CO}_{3}$ & 120 & 2 & 10 & $79\left(R={ }^{n} \mathrm{Pr}\right)$ & 11 \\
\hline 5 & ${ }^{\mathrm{n}} \mathrm{BuBr}$ & $\mathrm{Cs}_{2} \mathrm{CO}_{3}$ & 120 & 2 & 7 & $83\left(R={ }^{n} \mathrm{Bu}\right)$ & 10 \\
\hline 6 & $\mathrm{BnBr}$ & $\mathrm{K}_{2} \mathrm{CO}_{3}$ & 120 & 2 & 18 & $63(R=\mathrm{Bn})$ & $19^{\mathrm{a}}$ \\
7 & $\mathrm{BnBr}$ & $\mathrm{K}_{2} \mathrm{CO}_{3}$ & 130 & 3 & 16 & $63(R=\mathrm{Bn})$ & $21^{\mathrm{b}}$ \\
8 & $\mathrm{BnBr}$ & $\mathrm{Cs}_{2} \mathrm{CO}_{3}$ & 120 & 3 & 27 & $59(R=\mathrm{Bn})$ & $14^{\mathrm{c}}$ \\
\hline
\end{tabular}

${ }^{\mathrm{a}}$ Including $8 \%$ of the dibenzylated product; ${ }^{\mathrm{b}}$ Including $6 \%$ of the dibenzylated product; ${ }^{\mathrm{c}}$ Including $11 \%$ of the dibenzylated product.

Using ethyl iodide and $\mathrm{K}_{2} \mathrm{CO}_{3}$ at $120^{\circ} \mathrm{C}$ under $\mathrm{MW}$ and solvent-free conditions, the proportion of the ethyl-substituted product $(\mathbf{1 8}, R=\mathrm{Et})$ was $82 \%$ after $2 \mathrm{~h}$ irradiation (Table 4, entry 1$)$. The yield remained unchanged by increasing both the temperature and reaction time. The use of $\mathrm{Cs}_{2} \mathrm{CO}_{3}$ instead of $\mathrm{K}_{2} \mathrm{CO}_{3}$ as the base led to similar results (Table 4, entry 2).

Applying propyl bromide, the use of $\mathrm{Cs}_{2} \mathrm{CO}_{3}$ was better than that of $\mathrm{K}_{2} \mathrm{CO}_{3}$ (Table 4, entries 3 and 4).

In the alkylation with $n$-butyl bromide using $\mathrm{Cs}_{2} \mathrm{CO}_{3}$ at $120^{\circ} \mathrm{C}$, the yield of the product $\left(\mathbf{1 8}, R={ }^{n} \mathrm{Bu}\right)$ was $83 \%$ (Table 4 , entry 5 ).

The benzylation was also investigated in detail. The optimum conditions comprised $120{ }^{\circ} \mathrm{C}$ and $2 \mathrm{~h}$ using $\mathrm{K}_{2} \mathrm{CO}_{3}$ (Table 4, entry 6). An increase of the temperature and reaction time did not improve the yield (Table 4, entry 7). The conversion ( $73 \% v s .82 \%)$ and the proportion of the by-product (14\%vs. $19 \%$ ) were lower (Table 4, entry 6 vs. Table 4, entry 8) applying $\mathrm{Cs}_{2} \mathrm{CO}_{3}$ instead of $\mathrm{K}_{2} \mathrm{CO}_{3}$.

These reactions generated the mono-alkylated product in good yields without PTC under MW conditions. In the presence of phase transfer catalyst, the conversion was decreased, and the rate of the by-products was dramatically increased. The main by-products of the propylation reactions were the propylated ethoxycarbonylmethylphosphonate with ethyl- $n$-propyl (19) and di-n-propyl ester (20) functions. The main by-product of the benzylation was the dibenzylated diethyl ethoxycarbonylmethylphosphonate (21) (Scheme 11).

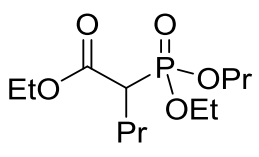

19

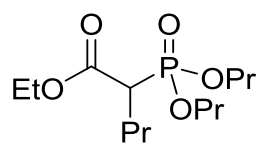

20<smiles>CCOC(=O)C(Br)(Br)P(=O)(OCC)OCC</smiles>

21

Scheme 11. By-products of the alkylation of ethoxycarbonylmethylphosphonate (17).

Comparative thermal experiments were also carried out in boiling acetonitrile for $24 \mathrm{~h}$ (Scheme 12, Table 5). 


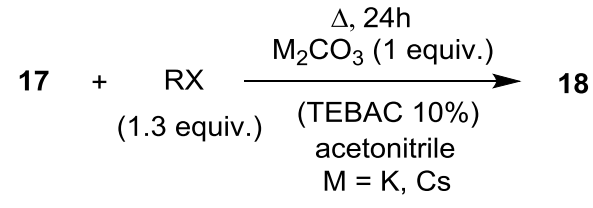

$$
\begin{aligned}
& \mathrm{RX}=\mathrm{Etl},{ }^{\mathrm{n}} \mathrm{PrBr},{ }^{\mathrm{n}} \mathrm{BuBr}
\end{aligned}
$$

Scheme 12. Alkylation of diethyl ethoxycarbonylmethylphosphonate (17).

Table 5. Alkylation of diethyl ethoxycarbonylmethylphosphonate (17) under conventional heating in boiling acetonitrile for $24 \mathrm{~h}$.

\begin{tabular}{|c|c|c|c|c|c|c|}
\hline \multirow{2}{*}{ Entry } & \multirow{2}{*}{$R \mathbf{X}$} & \multirow{2}{*}{$\mathrm{M}_{2} \mathrm{CO}_{3}$} & \multirow{2}{*}{ TEBAC (10\%) } & \multicolumn{3}{|c|}{ Composition (\%) } \\
\hline & & & & 17 & 18 & Other \\
\hline 1 & EtI & $\mathrm{K}_{2} \mathrm{CO}_{3}$ & + & 79 & $11(R=\mathrm{Et})$ & 10 \\
\hline 2 & ${ }^{n} \mathrm{PrBr}$ & $\mathrm{K}_{2} \mathrm{CO}_{3}$ & + & 80 & $14\left(R={ }^{n} \operatorname{Pr}\right)$ & 6 \\
\hline 3 & ${ }^{n} \mathrm{BuBr}$ & $\mathrm{K}_{2} \mathrm{CO}_{3}$ & + & 72 & $28\left(R={ }^{n} \mathrm{Bu}\right)$ & - \\
\hline 4 & EtI & $\mathrm{Cs}_{2} \mathrm{CO}_{3}$ & - & 24 & $74(R=\mathrm{Et})$ & $2^{a}$ \\
\hline 5 & ${ }^{n} \mathrm{PrBr}$ & $\mathrm{Cs}_{2} \mathrm{CO}_{3}$ & - & 55 & $45\left(R={ }^{n} \operatorname{Pr}\right)$ & $-b$ \\
\hline 6 & ${ }^{n} \mathrm{BuBr}$ & $\mathrm{Cs}_{2} \mathrm{CO}_{3}$ & - & 31 & $69\left(R={ }^{n} \mathrm{Bu}\right)$ & $-c$ \\
\hline
\end{tabular}

${ }^{\mathrm{a}-\mathrm{c}}$ No change on prolonged heating.

The comparative experiments were carried out using $\mathrm{K}_{2} \mathrm{CO}_{3}$ in the presence of a catalyst and with $\mathrm{Cs}_{2} \mathrm{CO}_{3}$ in the absence of a catalyst. When $\mathrm{K}_{2} \mathrm{CO}_{3}$ was used with TEBAC, the conversions remained low with all three alkylating agents after a reflux of $24 \mathrm{~h}$ (Table 5, entries 1-3). The use of $\mathrm{Cs}_{2} \mathrm{CO}_{3}$ without catalyst resulted in higher conversions (Table 5, entries 4-6).

The alkylations took place in a shorter reaction time and with better conversions under MW conditions in the absence of a catalyst. The catalyst- and solvent-free MW-assisted method is much more efficient than the conventional phase transfer catalyzed accomplishment (Table 5, entries 1-3).

\subsection{Alkylation of Diethyl Cyanomethylphosphonate under MW and Solvent-Free Conditions}

The alkylation methods for diethyl cyanomethylphosphonate (22) are similar to those described for diethyl ethoxycarbonylmethylphosphonate in the previous chapter.

In most cases, $\mathrm{NaH}$ was used as the base in the glyme [41,42] or DMF [43,44]. Potassium was also applied as the base in the alkylation of (22) using 1,4-dioxane and diethyl ether [45].

The liquid-liquid phase transfer catalytic methylation of model compound (22) was carried out using aqueous $\mathrm{NaOH}$ and DCM in the presence of TBAB catalyst (Scheme 13) [46].

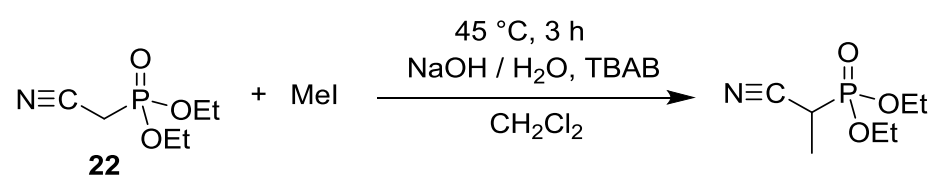

Scheme 13. Alkylation of diethyl cyanomethylphosphonate (22) using aqueous $\mathrm{NaOH}$ solution. 
These reactions were also studied by Keglevich and co-workers under MW conditions (Scheme 14, Table 6) [47]. The traditionally heated alkylations were performed in boiling acetonitrile for $24 \mathrm{~h}$. The $\mathrm{MW}$-assisted reactions were complete after $1-2 \mathrm{~h}$ at $100-120^{\circ} \mathrm{C}$ in the absence of any solvent.

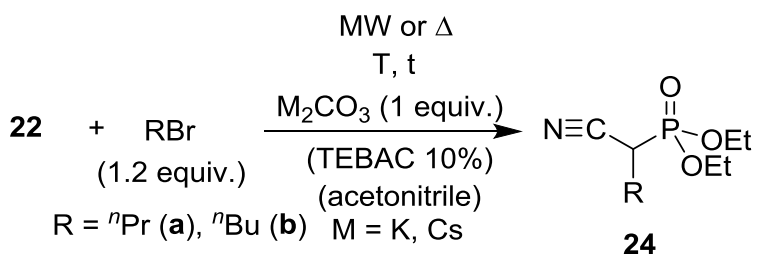

Scheme 14. The alkylation of diethyl cyanomethylphosphonate (22) under thermal and MW conditions.

Table 6. The alkylation of diethyl cyanomethylphosphonate (22) under thermal and MW conditions.

\begin{tabular}{ccccccccccc}
\hline \multirow{2}{*}{ Entry } & $\boldsymbol{R} \mathbf{X}$ & $\boldsymbol{M}$ & Mode of heating & $\boldsymbol{T}\left({ }^{\circ} \mathbf{C}\right)$ & $\boldsymbol{t}(\mathbf{h})$ & Solvent & TEBAC $(\mathbf{1 0} \%)$ & \multicolumn{3}{c}{ Composition (\%) } \\
\hline 1 & ${ }^{n} \mathrm{PrBr}$ & $\mathrm{K}$ & $\Delta$ & 82 & 24 & $\mathrm{MeCN}$ & - & 53 & $45\left(R={ }^{n} \mathrm{Pr}\right)$ & 2 \\
2 & ${ }^{n} \mathrm{PrBr}$ & $\mathrm{K}$ & $\Delta$ & 82 & 24 & $\mathrm{MeCN}$ & + & 26 & $37\left(R={ }^{n} \mathrm{Pr}\right)$ & 37 \\
3 & ${ }^{n} \mathrm{PrBr}$ & $\mathrm{Cs}$ & $\Delta$ & 82 & 24 & $\mathrm{MeCN}$ & - & 7 & $84\left(R={ }^{n} \mathrm{Pr}\right)$ & 9 \\
4 & ${ }^{n} \mathrm{PrBr}$ & $\mathrm{Cs}$ & $\Delta$ & 82 & 24 & $\mathrm{MeCN}$ & + & 2 & $67\left(R={ }^{n} \mathrm{Pr}\right)$ & 31 \\
5 & ${ }^{n} \mathrm{PrBr}$ & $\mathrm{K}$ & $\mathrm{MW}$ & 100 & 2 & - & - & 13 & $70\left(R={ }^{n} \operatorname{Pr}\right)$ & 17 \\
6 & ${ }^{n} \mathrm{PrBr}$ & $\mathrm{K}$ & $\mathrm{MW}$ & 120 & 1 & - & - & 20 & $58\left(R={ }^{n} \mathrm{Pr}\right)$ & 22 \\
7 & ${ }^{n} \mathrm{PrBr}$ & $\mathrm{Cs}$ & $\mathrm{MW}$ & 120 & 1 & - & - & 4 & $33\left(R={ }^{n} \mathrm{Pr}\right)$ & 63 \\
\hline 8 & ${ }^{n} \mathrm{BuBr}$ & $\mathrm{Cs}$ & $\Delta$ & 82 & 24 & $\mathrm{MeCN}$ & - & 3 & $90\left(R={ }^{n} \mathrm{Bu}\right)$ & 7 \\
9 & ${ }^{n} \mathrm{BuBr}$ & $\mathrm{K}$ & $\mathrm{MW}$ & 120 & 2 & - & - & 20 & $65\left(R={ }^{n} \mathrm{Bu}\right)$ & 15 \\
\hline
\end{tabular}

In the alkylation with propyl bromide under conventional heating, the use of $\mathrm{Cs}_{2} \mathrm{CO}_{3}$ was more efficient than that of $\mathrm{K}_{2} \mathrm{CO}_{3}$ in the absence of phase transfer catalyst in acetonitrile (the proportion of product 24 a was $84 \%$ vs. $45 \%$, respectively) (Table 6, entries 1 and 3 ). In the presence of TEBAC, the amount of the expected product (24a) was decreased, while the relative proportion of the by-products was increased (Table 6, entries 2 and 4). A rather good result was achieved under MW conditions using $\mathrm{K}_{2} \mathrm{CO}_{3}$ at $100{ }^{\circ} \mathrm{C}$ for $2 \mathrm{~h}\left(70 \%\right.$ of $\mathbf{2 4 a}$ was obtained) (Table 6, entry 5). Applying $\mathrm{K}_{2} \mathrm{CO}_{3}$ at $120{ }^{\circ} \mathrm{C}$, the conversion was $80 \%$ after $1 \mathrm{~h}$ (Table 6, entry 6). Replacing $\mathrm{K}_{2} \mathrm{CO}_{3}$ with $\mathrm{Cs}_{2} \mathrm{CO}_{3}$, the proportion of the by-products was rather high (63\%) (Table 6, entry 7). The best results are marked by entries 3 and 5 covering a thermal and MW experiments, respectively.

The alkylation of diethyl cyanomethylphosphonate (22) with butyl bromide led to similar results. An almost complete conversion was achieved in boiling acetonitrile in the presence of $\mathrm{Cs}_{2} \mathrm{CO}_{3}$, without TEBAC (Table 6, entry 8). Under MW conditions using $\mathrm{K}_{2} \mathrm{CO}_{3}$ at $120{ }^{\circ} \mathrm{C}$ for $2 \mathrm{~h}$, the yield of the compound (24b) was 65\% (Table 6, entry 9).

Increasing the amount of the catalyst and the excess of butyl bromide, the conversion was complete, but the proportion of by-products (25) and (26) was increased (Scheme 15, Table 7). 


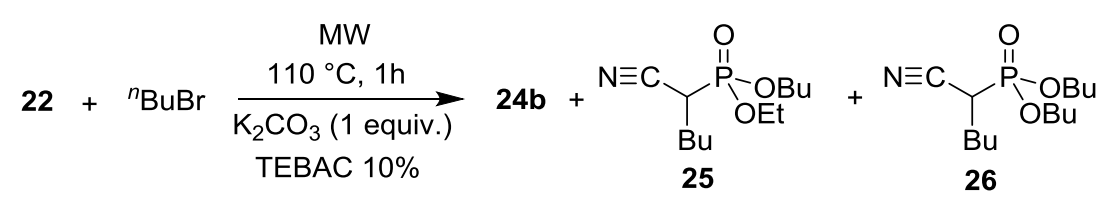

Scheme 15. The alkylation of diethyl cyanomethylphosphonate (22) with butyl bromide in the presence of triethylbenzylammonium chloride (TEBAC).

Table 7. The alkylation of diethyl cyanomethylphosphonate (22) with butyl bromide under solventless MW conditions in the presence of triethylbenzylammonium chloride (TEBAC).

\begin{tabular}{cccccccc}
\hline \multirow{2}{*}{ Entry } & \multirow{2}{*}{${ }^{n}$ BuBr (equiv.) } & \multirow{2}{*}{ TEBAC (\%) } & \multicolumn{5}{c}{ Composition (\%) } \\
\cline { 4 - 8 } & 2.4 & 20 & 0 & 20 & 38 & 21 & 21 \\
1 & 3.6 & 30 & 0 & 14 & 37 & 25 & 24 \\
\hline
\end{tabular}

3.3. Alkylation of Tetraethyl Methylenebisphosphonate and Bis(diphenylphosphinoyl)methane under MW Conditions

A widely used method for the alkylation of tetraethyl methylenebisphosphonate (27) applies $\mathrm{NaH}$ as the base in toluene [48-50]. In other methods, sodium in ether [51] or potassium in xylene [52] were used. A liquid-liquid phase transfer catalytic ethylation was also described using aqueous $\mathrm{KOH}$ and DCM [53].

Keglevich and co-workers studied the model reaction under discussion under MW conditions [19].

Performing the alkylation of tetraethyl methylenebisphosphonate $(27)$ with ethyl iodide at $140{ }^{\circ} \mathrm{C}$ in the presence of 1 equiv. of $\mathrm{Cs}_{2} \mathrm{CO}_{3}$, the conversion was complete and the main product was the $C$-ethyl methylenebisphosphonate (28) (97\%); the dialkylated by-product (29) was formed only in 3\% proportion (Scheme 16).

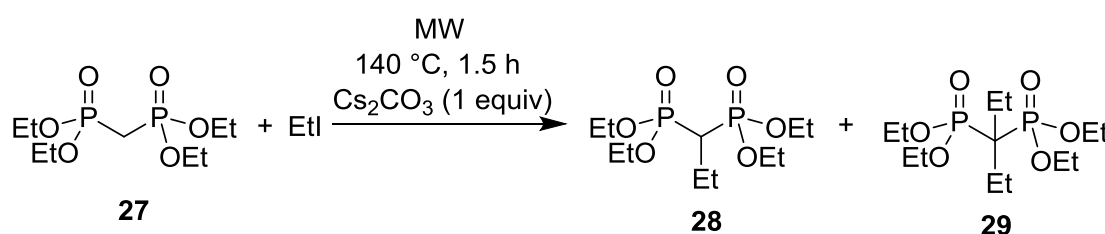

Scheme 16. Alkylation of tetraethyl methylenebisphosphonate (27) with EtI.

In reaction with propyl-bromide using 1 equiv. of $\mathrm{Cs}_{2} \mathrm{CO}_{3}$ at $120^{\circ} \mathrm{C}$ for $4 \mathrm{~h}$, a mixture of products 30 , 31 and 32 was formed. The proportion of the propylated product (30) was 57\%, while the products formed by transesterification (31 and 32) were present in 33\% and 10\% (Scheme 17).

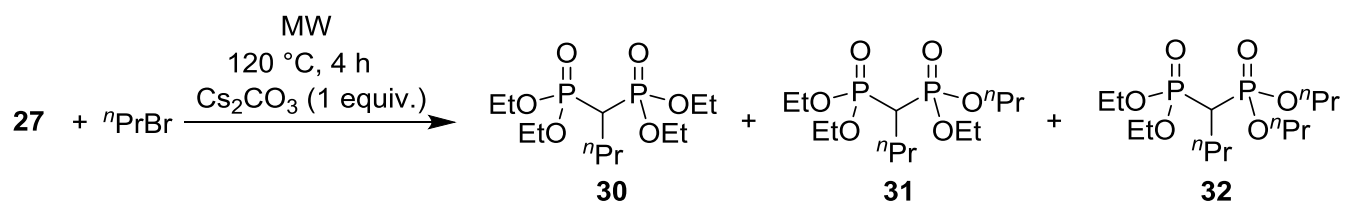

Scheme 17. Alkylation of tetraethyl methylenebisphosphonate (27) with $\mathrm{PrBr}$. 
When tetraethyl methylenebisphosphonate (27) was reacted with benzyl bromide under conventional heating $\left(82{ }^{\circ} \mathrm{C} / 40 \mathrm{~h}\right)$ in the presence of 1 equiv of $\mathrm{K}_{2} \mathrm{CO}_{3}$ and $25 \%$ of TEBAC, the isolated yield of compound (33) was $83 \%$ and no by-product was formed. Under MW conditions at $120{ }^{\circ} \mathrm{C}$ for $1.5 \mathrm{~h}$, the derivative formed by transesterification (34), 35\% was the main product, and only $5 \%$ of the expected component (33) was obtained (Scheme 18).

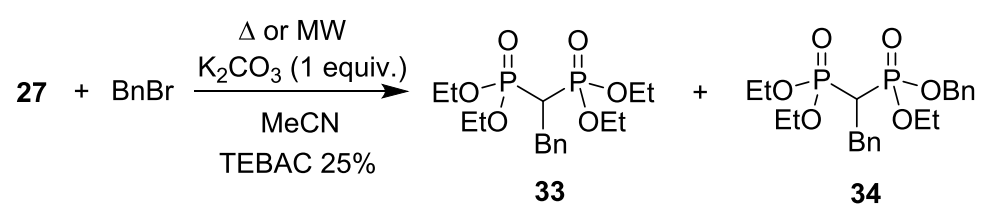

Scheme 18. Alkylation of tetraethyl methylenebisphosphonate (27) with $\mathrm{BnBr}$.

It can be concluded that the MW technique offers advantage in the alkylation of methylenebisphosphonates only when the alkyl groups of the two reactants are identical. Other advantages are that there is no need for any phase transfer catalyst, and the reaction time is much shorter.

The alkylation of bis(diphenylphosphinoyl)methane (35) was also investigated (Scheme 19) [47]. The benzylation of $\mathbf{3 5}$ was investigated under thermal and MW conditions. In all cases, acetonitrile was used as the solvent and 1 equiv. of $\mathrm{Cs}_{2} \mathrm{CO}_{3}$ as the base. Under conventional heating in the presence of $10 \%$ of TEBAC, the conversion was $60 \%$ after 1 day (Table 8 , entry 1). Under MW irradiation in the absence of a phase transfer catalyst at $120^{\circ} \mathrm{C}$, after $1.5 \mathrm{~h}$, the conversion was only $21 \%$ (Table 8 , entry 2 ), while using TEBAC, after a reaction time of $3 \mathrm{~h}$, the conversion was $57 \%$ (Table 8 , entry 3 ).

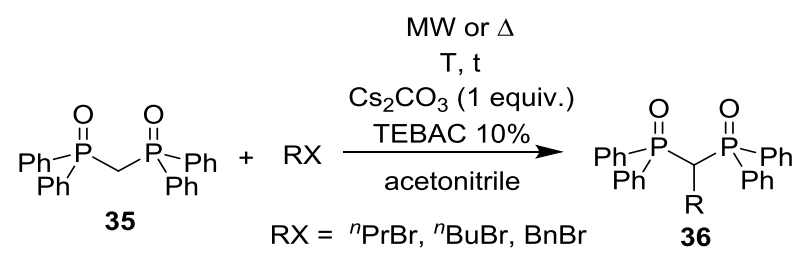

Scheme 19. Alkylation of bis(diphenylphosphinoyl)methane (35).

Table 8. Benzylation of bis(diphenylphosphinoyl)methane (35) in the presence of $\mathrm{Cs}_{2} \mathrm{CO}_{3}$ and TEBAC in acetonitrile.

\begin{tabular}{ccccccc}
\hline Entry & $\begin{array}{c}\text { Mode of } \\
\text { heating }\end{array}$ & $\boldsymbol{T}\left({ }^{\circ} \mathbf{C}\right)$ & $\begin{array}{c}\boldsymbol{t} \\
\mathbf{( h )}\end{array}$ & $\begin{array}{c}\text { TEBAC } \\
(\mathbf{1 0 \%})\end{array}$ & $\begin{array}{c}\text { Conversion } \\
(\mathbf{\%})\end{array}$ & $\begin{array}{c}\text { Yield of 36 } \boldsymbol{R}=\mathbf{B n} \\
\mathbf{( \% )}\end{array}$ \\
\hline 1 & $\Delta$ & 82 & 24 & + & 60 & 44 \\
2 & $\mathrm{MW}$ & 120 & 1.5 & - & 21 & - \\
3 & $\mathrm{MW}$ & 120 & 3 & + & 57 & 45 \\
\hline
\end{tabular}

The propylation and butylation were investigated under $\mathrm{MW}$ irradiation in acetonitrile using $\mathrm{Cs}_{2} \mathrm{CO}_{3}$ and TEBAC. At $180{ }^{\circ} \mathrm{C}$ after a reaction time of $4 \mathrm{~h}$, the conversion was $64 \%$ (Table 9, entry 1). The conversion of the butylation under similar conditions was $73 \%$ (Table 9 , entry 2 ).

In the MW-assisted alkylation reactions of bis(diphenylphosphinoyl)methane (35), contrary to the relations of the previously studied active methylene containing compounds with $\mathrm{P}=\mathrm{O}$ function (17, 22, 27), it was necessary to apply both a solvent and a catalyst. 
Table 9. Propylation and butylation of bis(diphenylphosphinoyl)methane (35) in the presence $\mathrm{Cs}_{2} \mathrm{CO}_{3}$ and TEBAC in acetonitrile under MW conditions.

\begin{tabular}{cccccccccc}
\hline \multirow{2}{*}{ Entry } & \multirow{2}{*}{$\mathbf{R X}$} & Mode of heating & $\boldsymbol{T}\left({ }^{\circ} \mathbf{C}\right)$ & $\boldsymbol{t}(\mathbf{h})$ & TEBAC (10\%) & \multicolumn{3}{c}{ Composition (\%) } \\
\cline { 7 - 10 } & & & & & & 35 & $\mathbf{3 6}$ & Other \\
\hline 1 & ${ }^{n} \mathrm{PrBr}$ & $\mathrm{MW}$ & 180 & 4 & + & 36 & $47\left(R={ }^{n} \operatorname{Pr}\right)$ & 17 \\
2 & ${ }^{n} \mathrm{BuBr}$ & $\mathrm{MW}$ & 180 & 4 & + & 26 & $52\left(R={ }^{n} \mathrm{Bu}\right)$ & 22 \\
\hline
\end{tabular}

\subsection{Dialkylation of Active Methylene Containing Compounds with $P=O-F u n c t i o n$}

The classical method for the dialkylation of simple active methylene containing compounds is well-known [54,55]. This procedure applies sodium ethylate in ethanol to generate an anion which then reacts with an alkyl halide, and this protocol is then repeated with the same or another alkyl halide.

In the case of the phase transfer catalyzed liquid-liquid two-phase alkylations, aqueous sodium hydroxide was employed as the base and dichloromethane [56] or chloroform [57] as the solvent. In the solid-liquid two-phase alkylations, $\mathrm{K}_{2} \mathrm{CO}_{3}$ was used in toluene [58], acetonitrile [59] or dimethylformamide [60].

The dialkylation of the title compounds have been studied less thoroughly. The ethoxycarbonylmethylphosphonate (17) was reacted in two steps, applying potassium in xylene [39] or in benzene [61]. Using different alkyl halides, the yields were in the range of 54\%-75\%. Another method applied sodium hydride in tetrahydrofuran [30,62] or in 1,2-dimethoxyethane [63]. In most cases, mixtures of the mono- and dialkylated products were formed. In the literature, there is only one example for phase transfer catalyzed dialkylation. In the reaction of ethyl cyanomethylphosphonate (22) with methyl- ethyl- allyl- and benzyl halides in the presence of aqueous $\mathrm{NaOH}$ and TEBAC, the dialkylphosphonate derivatives were obtained in yields of $46 \%-88 \%$ [64].

A multi-step method was developed for the dialkylation of diethyl ethoxycarbonylmethylphosphonate (17) by Keglevich, Grün and, co-workers [65] (Scheme 20, Table 10). The diethylated, dipropylated, and dibutylated compounds (37) (Table 10, entries 1, 2, and 3, respectively) were obtained in good yields by the four-step solvent-free protocol under MW conditions. After each step, the crude reaction mixture was taken up in ethylacetate, the mixture was filtered, the filtrate evaporated (and analyzed) and reacted further.

Comparative thermal experiments using propyl iodide resulted in the formation of the dialkylated compound (37, $\left.R={ }^{n} \operatorname{Pr}\right)$ in only $11 \%$.

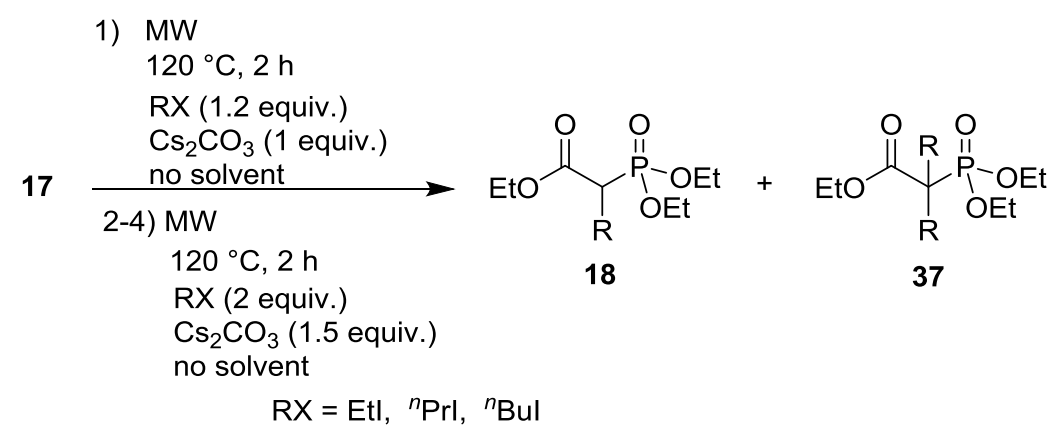

Scheme 20. Dialkylation of ethoxycarbonylmethylphosphonate (17). 
Table 10. MW-assisted dialkylation of ethoxycarbonylmethylphosphonate (17) by a four-step alkylating protocol.

\begin{tabular}{ccccccc}
\hline \multirow{2}{*}{ Entry } & \multirow{2}{*}{ Step } & \multirow{2}{*}{$\boldsymbol{R} \mathbf{X}$} & \multicolumn{4}{c}{ Composition (\%) } \\
\cline { 4 - 7 } & & & $\mathbf{1 7}$ & $\mathbf{1 8}$ & $\mathbf{3 7}$ & Other \\
\hline \multirow{2}{*}{1} & 1. & EtI & 11 & $83(R=\mathrm{Et})$ & $6(R=\mathrm{Et})$ & - \\
& 2. & EtI & - & $41(R=\mathrm{Et})$ & $59(R=\mathrm{Et})$ & - \\
& 3. & EtI & - & $9(R=\mathrm{Et})$ & $91(R=\mathrm{Et})$ & - \\
& 4. & EtI & - & $2(R=\mathrm{Et})$ & $98(R=\mathrm{Et})$ & - \\
\hline \multirow{2}{*}{2} & 1. & ${ }^{n} \mathrm{PrI}$ & 12 & $77\left(R={ }^{n} \mathrm{Pr}\right)$ & $3\left(R={ }^{n} \mathrm{Pr}\right)$ & 8 \\
& 4. & ${ }^{n} \mathrm{PrI}$ & - & $16\left(R={ }^{n} \mathrm{Pr}\right)$ & $70\left(R={ }^{n} \mathrm{Pr}\right)$ & 14 \\
\hline \multirow{2}{*}{3} & 1. & ${ }^{n} \mathrm{BuI}$ & 14 & $77\left(R={ }^{n} \mathrm{Bu}\right)$ & $5\left(R={ }^{n} \mathrm{Bu}\right)$ & 4 \\
& 4. & ${ }^{n} \mathrm{BuI}$ & - & $13\left(R={ }^{n} \mathrm{Bu}\right)$ & $76\left(R={ }^{n} \mathrm{Bu}\right)$ & 11 \\
\hline
\end{tabular}

The role of the phase transfer catalyst was also investigated in this method. In the ethylation of the substrate (17) applying $\mathrm{K}_{2} \mathrm{CO}_{3}$ or $\mathrm{Cs}_{2} \mathrm{CO}_{3}$ as the base, TEBAC or tetrabutylammonium bromide (TBAB) were used as phase transfer catalysts (Scheme 21, Table 11). Using $\mathrm{Cs}_{2} \mathrm{CO}_{3}$ and $10 \%$ of TEBAC, the proportion of the dialkylated product was much less after the second step than without phase transfer catalyst (Table 11, entry $1 v s$. Table 10, entry 1). When TBAB was the catalyst, the proportion was again lower, but there was no by-product (Table 11, entry 2 vs. Table 10, entry 1). The formation of the by-products suggested that TEBAC also took part in the reaction as an alkylating agent.

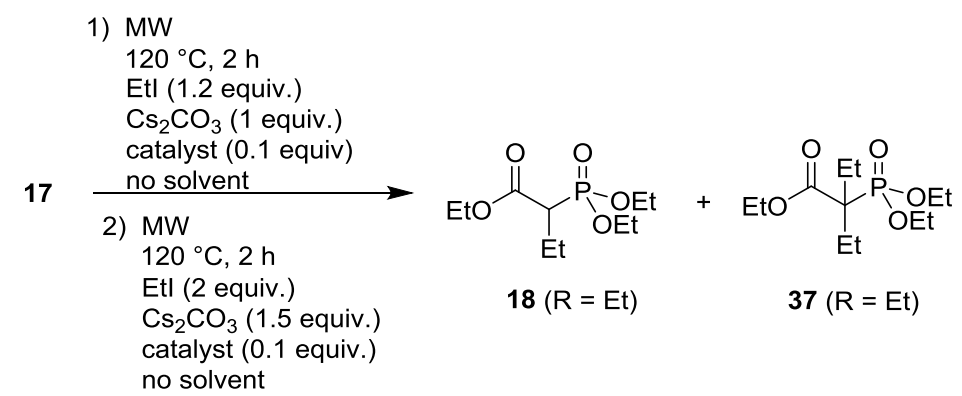

Scheme 21. Two-step ethylation of ethoxycarbonylmethylphosphonate (17) in the presence of a phase transfer catalyst.

Table 11. Two-step ethylation of ethoxycarbonylmethylphosphonate (17) with ethyl iodide under MW conditions in the presence of a TEBAC or tetrabutylammonium bromide (TBAB).

\begin{tabular}{cccccccc}
\hline \multirow{2}{*}{ Entry } & \multirow{2}{*}{ Step } & \multirow{2}{*}{ Phase transfer catalyst } & $\mathbf{M}_{2} \mathrm{CO}_{3}$ & \multicolumn{4}{c}{ Composition (\%) } \\
\cline { 5 - 8 } & & & & $\mathbf{1 7}$ & $\mathbf{1 8}(\boldsymbol{R}=\mathbf{E t})$ & $\mathbf{3 7}(\boldsymbol{R}=\mathbf{E t})$ & By-products \\
\hline \multirow{2}{*}{1} & 1. & TEBAC & $\mathrm{Cs}_{2} \mathrm{CO}_{3}$ & 8 & 75 & 7 & 10 \\
& 2. & TEBAC & $\mathrm{Cs}_{2} \mathrm{CO}_{3}$ & - & 62 & 21 & 17 \\
\hline \multirow{2}{*}{2} & 1. & TBAB & $\mathrm{Cs}_{2} \mathrm{CO}_{3}$ & - & 75 & 25 & - \\
& 2. & TBAB & $\mathrm{Cs}_{2} \mathrm{CO}_{3}$ & - & 57 & 43 & - \\
\hline
\end{tabular}

The synthesis of disubstituted compounds with two different alkyl groups was also investigated (Scheme 22, Table 12). The first step was the monoalkylation of the starting material with propyl iodide, 
butyl bromide or benzyl bromide (Table 12, entries 1, 2 and 3, respectively) in the presence of $\mathrm{Cs}_{2} \mathrm{CO}_{3}$ under solvent-free MW conditions. This was then followed by ethylation with EtI in two or three steps, also in the presence of $\mathrm{Cs}_{2} \mathrm{CO}_{3}$. The proportion of the by-products was significantly higher, as compared to the cases when identical alkyl groups were introduced. (Table 10).

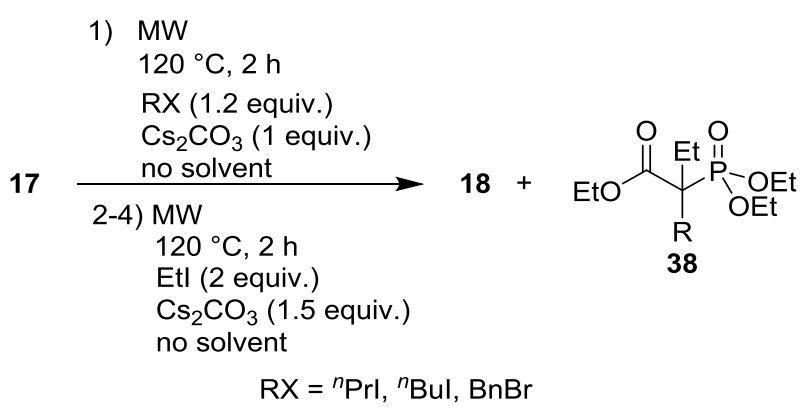

Scheme 22. Synthesis of ethoxycarbonylmethylphosphonates containing different alkyl groups on the carbon atom $(\mathbf{3 8})$.

Table 12. MW-assisted synthesis of ethoxycarbonylmethylphosphonates with different alkyl groups (37).

\begin{tabular}{ccccccc}
\hline \multirow{2}{*}{ Entry } & \multirow{2}{*}{ Step } & \multirow{2}{*}{$\boldsymbol{X}$} & \multicolumn{4}{c}{ Composition (\%) } \\
\cline { 4 - 7 } & & & $\mathbf{1 7}$ & $\mathbf{1 8}$ & $\mathbf{3 8}$ & Other \\
\hline 1 & 1. & PrI & 12 & $77\left(R={ }^{n} \mathrm{Pr}\right)$ & - & 11 \\
& 2. & EtI & - & $37\left(R={ }^{n} \mathrm{Pr}\right)$ & $43\left(R={ }^{n} \mathrm{Pr}\right)$ & 20 \\
& 3. & EtI & - & $16\left(R={ }^{n} \mathrm{Pr}\right)$ & $59\left(R={ }^{n} \mathrm{Pr}\right)$ & 25 \\
& 4. & EtI & - & $1\left(R={ }^{n} \mathrm{Pr}\right)$ & $74\left(R={ }^{n} \mathrm{Pr}\right)$ & 25 \\
\hline \multirow{2}{*}{2} & 1. & $\mathrm{BuBr}$ & 14 & $79\left(R={ }^{n} \mathrm{Bu}\right)$ & - & 7 \\
& 2. & EtI & - & $51\left(R={ }^{n} \mathrm{Bu}\right)$ & $26\left(R={ }^{n} \mathrm{Bu}\right)$ & 23 \\
& 3. & EtI & - & $25\left(R={ }^{n} \mathrm{Bu}\right)$ & $50\left(R={ }^{n} \mathrm{Bu}\right)$ & 25 \\
& 4. & EtI & - & $6\left(R={ }^{n} \mathrm{Bu}\right)$ & $71\left(R={ }^{n} \mathrm{Bu}\right)$ & 23 \\
\hline \multirow{2}{*}{3} & 1. & $\mathrm{BnBr}$ & - & $75(R=\mathrm{Bn})$ & - & 25 \\
& 2. & EtI & - & $21(R=\mathrm{Bn})$ & $53(R=\mathrm{Bn})$ & 26 \\
& 3. & EtI & - & - & $74(R=\mathrm{Bn})$ & 26 \\
\hline
\end{tabular}

In summary, a multi-step MW-assisted catalyst- and solvent-free method was shown to be suitable for the synthesis of dialkyl ethoxycarbonylmethylphosphonates.

\section{Summary}

In this overview, the phase transfer catalyzed methods for the mono-alkylation and dialkylation of typical active methylene containing substrates including $\mathrm{P}=\mathrm{O}$-functionalized derivatives were summarized beyond the classical methods. In a more environmentally-friendly approach, the phase transfer catalyst may be substituted by MW irradiation. In such MW-assisted solid-liquid phase $C$-alkylations, there was no need to use any catalyst. Moreover, in these cases, the use of an onium salt led to side reactions. Repetition of the MW-promoted alkylations by newer portions of the reagents resulted in dialkylation. 


\section{Acknowledgments}

Support from the Hungarian Scientific Research Fund (OTKA K 83118) is gratefully acknowledged.

\section{Author Contributions}

Alajos Grün and Erika Bálint wrote the first draft of the manuscript that was then refined by supervisor György Keglevich.

\section{Conflicts of Interest}

The authors declare no conflict of interest.

\section{References}

1. Loupy, A. Microwaves in Organic Synthesis; Wiley-VCH: Weinheim, Germany, 2002.

2. Deshayes, S.; Liagre, M.; Loupy, A.; Luche, J.L.; Petit, A. Microwave activation in phase transfer catalysis. Tetrahedron 1999, 55, 10851-10870.

3. Kappe, C.O. Controlled microwave heating in modern organic synthesis. Angew. Chem. Int. Ed. 2004, 43, 6250-6284.

4. Keglevich, G.; Kiss, N.Z.; Mucsi, Z.; Körtvélyesi, T. Insights into a surprising reaction: The microwave-assisted direct esterification of phosphinic acids. Org. Biomol. Chem. 2012, 10, 2011-2018.

5. Mucsi, Z.; Kiss, N.Z.; Keglevich, G. A quantum chemical study on the mechanism and energetics of the direct esterification, thioesterification and amidation of 1-hydroxy-3-methyl-3-phospholene 1-oxide. RSC Adv. 2014, 4, 11948-11954.

6. Glasnov, T.N.; Kappe, C.O. Microwave-assisted synthesis under continuous flow conditions. Macromol. Rapid Commun. 2007, 28, 395-410.

7. Strauss, C.R. On scale up of organic reactions in closed vessel microwave systems. Org. Process Res. Dev. 2009, 13, 915-923.

8. Cocagne, P.; Elguero, J.; Gallo, R. The present use and the possibilities of phase-transfer catalysis in drug synthesis. Heterocycles 1983, 20, 1379-1406.

9. Starks, C.M.; Liotta, C.L.; Halpern, M. Phase Transfer Catalysis-Fundamentals, Applications and Industrial Perspectives; Chapman \& Hall: New York, NY, USA; London, UK, 1994.

10. Makosza, M. Phase-transfer catalysis. A general green methodology in organic synthesis. Pure Appl. Chem. 2000, 27, 1399-1403.

11. Fedorynski, M.; Jezierska-Zieba, M.; Kakol, B. Phase transfer catalysis in pharmaceutical industry-where are we? Acta Pol. Pharm. 2008, 65, 647-654.

12. Wang, Y.; Deng, R.; Mi, A.; Jiang, Y. Solid-liquid phase transfer catalytic synthesis. XII. Microwave irradiated alkylation of diethyl malonate. Synth. Commun. 1995, 25, 1761-1764.

13. Deng, R.; Wang, Y.; Jiang, Y. Solid-liquid phase transfer catalytic synthesis. X. The rapid alkylation of ethyl acetoacetate under microwave irradiation. Synth. Commun. 1994, 24, 111-115.

14. Wang, Y.; Jiang, Y. Solid-liquid phase transfer catalytic synthesis. VIII. The rapid alkylation of ethyl phenylsulfonylacetate under microwave irradiation. Synth. Commun. 1992, 22, 2287-2291. 
15. Deng, R.; Wang, Y.; Jiang, Y. Solid-liquid phase transfer catalytic synthesis. XI. The convenient and efficient alkylation of ethyl phenylmercapto-acetate in the presence of quaternary ammonium salts under microwave irradiation. Synth. Commun. 1994, 24, 1917-1921.

16. Gumaste, V.K.; Khan, A.J.; Bhawal, B.M.; Deshmukh, A.R.A.S. Microwave assisted phase transfer catalysis: An efficient solvent free method for the synthesis of cyclopropane derivatives. Indian J. Chem. 2004, 43B, 420-423.

17. Keglevich, G.; Novák, T.; Vida, L.; Greiner, I. Microwave irradiation as an alternative to phase transfer catalysis in the liquid-solid phase, solvent-free $C$-alkylation of active methylene containing substrates. Green Chem. 2006, 8, 1073-1075.

18. Keglevich, G.; Majrik, K.; Vida, L.; Greiner, I. Microwave irradiation as a green alternative to phase transfer catalysis: solid-liquid phase alkylation of active methylene containing substrates under solvent-free conditions. Lett. Org. Chem. 2008, 5, 224-228.

19. Greiner, I.; Grün, A.; Ludányi, K.; Keglevich, G. Solid-liquid two-phase alkylation of tetraethyl methylenebisphosphonate under microwave irradiation. Heteroatom Chem. 2011, 22, 11-14.

20. Nakazato, A.; Kumagai, T.; Ohta, K.; Chaki, S.; Okuyama, S.; Tomisawa, K. Synthesis and SAR of 1-alkyl-2-phenylethylamine derivatives designed from $N, N$-dipropyl-4-methoxy-3-(2phenylethoxy)phenylethylamine to discover $\sigma_{1}$ ligands. J. Med. Chem. 1999, 42, 3965-3970.

21. Kuroda, C.; Kimura, Y.; Nogami, H. Intramolecular cyclization of 2-(alkoxycarbonyl)allylsilanes with ynones. Nucleophilic and electrophilic aspects of the 2-(alkoxycarbonyl)allylsilane moiety. J. Chem. Res. (S) 1998, 174-175.

22. Kuroda, C.; Tang, C.Y.; Tanabe, M.; Funakoshi, M. Proto- and iodo-lactonization reaction of substituted $\alpha, \beta: \gamma, \delta$-unsaturated carboxylic acid. Bull. Chem. Soc. Jap. 1999, 72, 1583-1587.

23. Kuroda, C.; Koshio, H.; Koito, A.; Sumiya, H.; Murase, A.; Hirono, Y. Nazarov cyclization of 4-cycloalkylidene-5-(trimethylsilyl)pent-1-en-3-one derivatives. Synthesis of spiro[4.5]decane, spiro[4.4]nonane, and their derivatives. Tetrahedron 2000, 56, 6441-6455.

24. Kuroda, C.; Honda, S.; Nogara, Y.; Koshio, H.; Shibue, T.; Takeshita, T. Synthesis of spiro[4.5]decane and bicyclo[4.3.0]nonane ring systems by self-cyclization of (Z)- and (E)-2-(trimethylsilylmethyl)pentadienal derivative. Tetrahedron 2004, 60, 319-331.

25. Nakano, M.; Atsuumi, S.; Koike, Y.; Tanaka, S.; Funabashi, H.; Hashimoto, J.; Ohkubo, M.; Morishima, H. Synthesis of a homostatine-containing renin inhibitor which incorporates a sulfonemethylene isostere at its $N$-terminus. Bull. Chem. Soc. Jap. 1990, 63, 2224-2232.

26. Gomez-Monterrey, I.; Turcaud, S.; Lucas, E.; Bruetschy, L.; Roques, B.P.; Fournib-Zaluski, M.-C. Exploration of neutral endopeptidase active site by a series of new thiol-containing inhibitors. J. Med. Chem. 1993, 36, 87-94.

27. Chen, H.; Noble, F.; Mothe, A.; Meudal, H.; Coric, P.; Danascimento, S.; Roques, B. P.; George, P.; Fournib-Zaluski, M.-C. Phosphinic derivatives as new dual enkephalin-degrading enzyme inhibitors: Synthesis, biological properties, and antinociceptive activities. J. Med. Chem. 2000, 43, 1398-1408.

28. Dhokte, U.P.; Rao, A.S. Synthesis of the pheromones, (E)-3,7-dimethyl-2,7-octadienyl propionate, (E)-3,7-dimethyl-2-octene-1,8-diol and frontalin from a common intermediate. Synth. Commun. 1988, 18, 811-822. 
29. Zhang, J.; Loh, T.-P. Ruthenium- and rhodium-catalyzed cross-coupling reaction of acrylamides with alkenes: efficient access to (Z,E)-dienamides. Chem. Commun. 2012, 48, 11232-11234.

30. Doran, R.; Duggan, L.; Singh, S.; Duffy, C.D.; Guiry, P.J. Asymmetric synthesis of (+)-tanikolide and the $\beta$-methyl-substituted analogues of (+)-tanikolide and (-)-malyngolide. Eur. J. Org. Chem. 2011, 35, 7097-7106.

31. Stritzke, K.; Schulz, S.; Nishida, R. Absolute configuration and synthesis of $\beta$ - and $\delta$-lactones present in the pheromone system of the giant white butterfly Idea leuconoe. Eur. J. Org. Chem. 2002, 22, 3884-3892.

32. Senter, T.J.; Fadeyi, O.O.; Lindsley, C.W. Enantioselective total synthesis of (+)-amabiline. Org. Lett. 2012, 14, 1869-1871.

33. Ferguson, A.C.; Adlington, R.M.; Martyres, D.H.; Rutledge, P.J.; Cowley, A.; Baldwin, J.E. Total synthesis of a novel 2-thiabicyclo[3.2.0]heptan-6-one analogue of penicillin N. Tetrahedron 2003, 59, 8233-8243.

34. Wuts, P.G.M.; Putt, S.R.; Ritter, A.R. Synthesis of the dipeptide hyroxyethylene isostere of Leu-Val, a transition state mimic for the control of enzyme function. J. Org. Chem. 1988, 53, 4503-4508.

35. Liao, C.-C.; Zhu, J.-L. Investigation on Lewis acid mediated Diels-Alder reactions of 2-phosphono2-alkenoates. Application to total synthesis of $(+/-)$ - $\alpha$-Alasken-8-one via reductive alkylation of resulting adduct. J. Org. Chem. 2009, 74, 7873-7884.

36. Pelotier, B.; Holmes, T.; Piva, O. Synthesis of anti-Alzheimer $(R)$-arundic acid. Tetrahedron Asymmetry 2005, 16, 1513-1520.

37. Kirschleger, B.; Queignec, R. Heterogeneous mediated alkylation of ethyl diethylphosphonoacetate. A “one pot" access to $\alpha$-alkylated acrylic esters. Synthesis 1986, 926-928.

38. Nieminen, S.; Payne, T.G.; Senn, P.; Tamm, C. Biosynthesis of the rubratoxins. Helv. Chim. Acta 1981, 64, 2162-2174.

39. Kosolapoff, G.M.; Stephen Powell, J.S. Alkylation of triethyl phosphonoacetate and related esters. J. Am. Chem. Soc. 1950, 72, 4198-4200.

40. Grün, A.; Blastik, Z.; Drahos, L.; Keglevich, G. Microwave-assisted alkylation of diethyl ethoxycarbonylmethylphosphonate under solventless conditions. Heteroatom Chem. 2012, 23, 241-246.

41. Simon, J.R.; Neidlein, R. Syntheses and chemical reactions of 1-cyano-1-isocyanoalkylphosphonic acid esters. Synthesis 2000, 1101-1108.

42. Compagnone, R.S.; Suarez, A.I.; Zambrano, J.L.; Pina, I.C.; Dominguez, J.N. A short and versatile synthesis of 3-substituted 2-aminoquinolines. Synth. Commun. 1997, 27, 1631-1641.

43. Bailey, P.D.; Morgan, K.M. A total asymmetric synthesis of (-)-suaveoline. Chem. Commun. 1996, 1479-1480.

44. Bailey, P.D.; Morgan, K.M. The total synthesis of (-)-suaveoline. J. Chem. Soc. Perkin Trans. 1 2000, 3578-3583.

45. Pudovik, A.N.; Lebedeva, N.M. Synthesis of esters of phosphonic and thiophosphonic acids. XXIV. Addition of phosphonoacetonitrile and its homologs to esters and nitriles of unsaturated carboxylic acids. Zh. Obshch Khim. 1955, 25, 2235-2240. 
46. Defacqz, N.; Touillaux, R.; Marchand-Brynaert, J. [4+2] Cycloaddition of N-buta-1,3dienylsuccinimide to gem-substituted vinyl phosphonates. J. Chem. Res. (S) 1998, 512-513.

47. Keglevich, G.; Grün, A.; Blastik, Z.; Greiner, I. Solid-liquid phase alkylation of $\mathrm{P}=\mathrm{O}$-functionalized $\mathrm{CH}$ acidic compounds utilizing phase transfer catalysis and microwave irradiation. Heteroatom Chem. 2011, 22, 174-179.

48. Hays, H.R.; Logan, T.J. gem-Diphosphinoalkanes. Preparation and characterization. J. Org. Chem. 1966, 31, 3391-3394.

49. Nguyen, L.M.; Niesor, E.; Bentzen, C.L. gem-Diphosphonate and gem-phosphonate-phosphate compounds with specific high density lipoprotein inducing activity. J. Med. Chem. 1987, 80, 1426-1433.

50. Roth, A.G.; Drescher, D.; Reamer, S.; Arenz, C.; Yang, Y.; Uhlig, S. Potent and selective inhibition of acid sphingomyelinase by bisphosphonates. Angewandte Chem. Int. Ed. 2009, 48, 7560-7563.

51. Kosolopoff, G.M. The chemistry of aliphatic phosphonic acids. I. Alkylation of methanediphosphonic acid. J. Am. Chem. Soc. 1953, 75, 1500-1501.

52. Goebel, R.; Richte, F.; Weichmann, H. Synthesis and reactivity of methylene bridged diphosphoryl compounds. Phosphorous, Sulfur 1992, 73, 67-80.

53. Cotton, F.A.; Schunn, R.A. Metal salts and complexes of dialkoxyphosphonylacetylmethanide ions. J. Am. Chem. Soc. 1963, 85, 2394-2402.

54. Henecka, H. Methoden Der Organischen Chemie (Houben-Weyl); Müller, E., Ed.; Thieme Verlag: Stuttgart, Germany, 1976; Part II, pp. 1435-1447.

55. Sustmann, R.; Korth, H.-G. Methoden Der Organischen Chemie (Houben-Weyl); Müller, E., Ed.; Thieme Verlag: Stuttgart, Germany, 1985; Part E5, Ch. 3.2.1.1.1.1.3, pp. 370-373.

56. Davis, B.R.; Hinds, M. G. Synthetic, Structural and vibrational spectroscopic studies in bismuth(III) halide/ $N, N^{\prime}$-aromatic bidentate base systems. IV. Bismuth(III) halide/ $N, N^{\prime}$-bidentate ligand (1:1) systems. Aust. J. Chem. 1997, 50, 309-320.

57. English, A.R.; Girard, D.; Jasys, V.J.; Martingano, R.J.; Kellogg, M.S. Orally effective acid prodrugs of the $\beta$-lactamase inhibitor sulbactam. J. Med. Chem. 1990, 33, 344-347.

58. Baumstark, A.L.; Choudhary, A.; Vasquez, P.C.; Dotrong, M. Synthesis of 4,4-dimethyl-3,4dihydro-3,3,5-trisubstituted-2 $H$-pyrazoles and $N$-benzoyl derivatives: Method for "Hydrolysis" of unreactive amides and carbamates. J. Heterocycl. Chem. 1990, 27, 291-294.

59. Quici, S.; Manfredi, A.; Raimondi, L.; Sironi, A. Synthesis and properties of new lipophilic macrotricyclic cylindrical cryptands. J. Org. Chem. 1995, 60, 6379-6388.

60. Viera, I.; Manta, E.; Gonzalez, L.; Mahler, G. Synthesis of enantiomerically enriched $\alpha, \alpha$-disubstituted $\beta, \gamma$-epoxy esters using hydrolytic kinetic resolution catalyzed by salenCo(III). Tetrahedron:Asymmetry 2010, 21, 631-635.

61. Bodnarchuk, N.D.; Malovik, V.V.; Derkach, G.I. Phosphono carboxylic acid derivatives. Zh. Obshch. Khim. 1970, 40, 1210-1217.

62. Khachik, F.; Beecher, G.R.; Li, B.W.; Englert, G.J. Synthesis of ${ }^{13}$ C-labelled (all-E,3R,3'R)- $\beta, \beta-$ carotene-3,3'-diol (zeaxanthin) at C(12), C(13), C(12'), and C(13') via all-E-2,7-dimethylocta-2,4,6triene-1,8-dial- ${ }^{13} \mathrm{C}_{4}$. Labelled Compd. Radiopharm. 1995, 36, 1157-1172. 
63. Noguchi, H.; Aoyama, T.; Shioiri, T. Total synthesis of analogs of topostin B, A DNA topoisomerase I inhibitor. Part 1. Synthesis of fragments of topostin B-1 analogs. Tetrahedron 1995, 51, 10531-10544.

64. Singh, R.J. Alkylation Studies; Part II: Bis-alkylation of diethyl cyanomethanephosphonate. Synthesis 1986, 762-763.

65. Grün, A.; Blastik, Z.; Drahos, L.; Keglevich, G. Dialkylation of diethyl ethoxycarbonylmethylphosphonate under microwave and solventless conditions. Heteroatom Chem. 2014, 25, 107-113.

(C) 2015 by the authors; licensee MDPI, Basel, Switzerland. This article is an open access article distributed under the terms and conditions of the Creative Commons Attribution license (http://creativecommons.org/licenses/by/4.0/). 